\title{
The Gap between Translator Training and the Translation Industry in Saudi Arabia
}

\author{
Basmah Ali Abu-ghararah \\ Taibah University, Al-Madinah Al-Munawarah, Saudi Arabia
}

\begin{abstract}
The purpose of this study was to evaluate the translation industry in Saudi Arabia in order to identify the professional contexts for which universities should be preparing translators. Following a review of the current state of the industry, the article examines the types of translation organizations found in the country and investigates the demands of today's translation market in Saudi Arabia. The most striking finding was that there is a huge gap between academic training and the requirements of the Saudi translation market. This study provides new beneficial insights for improving university translator-training programmes. It is suggested that the training programmes need to be constructed specifically to meet the demands of the Saudi translation market.

Keywords: Saudi translation market, translation competences, translation industry, translator training

Cite as: Abu-ghararah, B. A. (2017). The Gap between Translator Training and the Translation Industry in Saudi Arabia. Arab World English Journal for Translation \& Literary Studies, 1(4). DOI: http://dx.doi.org/10.24093/awejtls/vol1no4.8
\end{abstract}

